\author{
Achyut Nepal, Affiliated Honorary Research Fellow, Fil. Dr. Jan-U. Sandal Institute, Norway \\ ORCID ID: 0000-0003-2597-6037 \\ e-mail: provost@janusandal.no
}

\title{
Entrepreneurship and Economic Development
}

Introduction. An economic indicator can give an overall picture of the production, income and exchange of resources. The state practices to report the economic performance of the country is not able to depict the real picture of the overall situation of the society. Economic growth has been globally accepted to compare the status of development, but regardless of the high rate of economic growth, poverty still exists at a significant level. There are conflicting views about what actually shows real economic development. The entire results of the innovative efforts are generally attributed with the achievements of the government of the states. Although the role of the government in making innovative outcomes for the benefit of the public cannot be overlooked, it is not sufficient to merely look into the effort of the government. There are different people or communities playing roles in the development. Social entrepreneurs are self-motivated, skilled and expert people who work to bring changes to make life better for everybody in the society. They are not motivated by profit at the start; but will be rewarded with the entrepreneurial profit if their innovation is successful. Review of economic history reveals interpretation of the economic development is significantly influenced by the philosophy adopted by the state to govern. In this essay, along with the analysis of the relation between social entrepreneurship and development, core values of political theories and its relation with social entrepreneurship have been discussed. To emphasize the role of entrepreneurship in making life better as well as by facilitating the people and communities of underdeveloped geographical locations, a few cases of social entrepreneurship from Nepal are highlighted. Important findings include that social entrepreneurs are spontaneous but the state can play a encouraging role. Importantly, development cannot be found in the weight of economic indicators alone but shall be seen as the total situation of the society.

The study of economic development needs knowledge of political philosophy and political economy as well as a focus on organizing societies for the production of wealth, eradication of poverty and the arrangement of society to make it a just social order [9]. The state of economic development has to be seen not simply from the viewpoint of emerging or preceding economic conditions but from the total situation of the society, which is preceding or emerging. It is not possible to explain economic change only with the help of economic condition alone [24]. The method of calculating GDP as developed by John Maynard Keynes was a product of the Second World War. This method was initially developed by Simon Kuznets to estimate the national income of the US in 1932 to analyze fully the Great Depression. Later, in 1940, Keynes refined it by rejecting the government's income as a part of GDP as defined by Kuznet. Keynes defines GDP as private consumption, investment, and government spending. If government spending was not included, Britain's GDP at that time would fall despite the economic growth. This was the war time necessity seen by Keynes which continues till today. But GDP does not measure human well-being in proper sense [11].

Purpose. The objective of this study is to get insight into the circumstances leading to the emergence of social entrepreneurs and their contribution to the economy and society. In addition, the objective is to analyze the few selected cases of social entrepreneurship in Nepal and to analyze how the social entrepreneurships are proven to be the real drivers in transforming the society to equitability, with opportunities for everyone to flourish.

Result. Social entrepreneurship as a special form of management, which operates the production function with principles of ensuring increased value for all participants in the production process and the basic objective is to make the world a better place for everyone. Such a process of change is carried out by the individuals who are designated as social entrepreneurs [21]. Such individuals are skilled experts and self-motivated with a will to achieve something significant.

Conclusions. Economic growth as indicated by GDP alone is not a sign of economic development. Economic development shall be reflected in the total situation of the society where everybody has an opportunity to develop and everyone has a good life.

Keywords: Capitalism; Economic Development; Innovation; Socialism; Social Entrepreneurship.

\section{Удк 330}

Непал А., почесний науковий співробітник, Інститут Яна-Урбана Сандала, Фінстадйордет, Норвегія

\section{Підприємництво та економічний розвиток}

Економічні показники можуть надати загальну картину виробництва, доходу та обміну ресурсами. Державна практика звітування про економічні показники країни не може надати реальну картину ситуації в суспільстві. Існують суперечливі погляди щодо показника, який може об'єктивно охарактеризувати економічний розвиток. Мета цього дослідження - сформувати розуміння причин та чинників, що спричиняють появу соціальних підприємців, дослідити їх внесок в економіку та суспільство. Всі результати інноваційних зусиль, як правило, пов'язують 3 досягненнями уряду штатів. Хоча роль держави в отриманні інноваційних результатів є важливою, недостатньо розглядати лише зусилля уряду. Існують різні фізичні особи, громада, які впливають на цей розвиток. Соціальний

Acknowledgment. This scientific article was created at the Fil. Dr. Jan-U. Sandal Institute, Finstadjordet, Norway, under the supervision of Prof. Fil. Dr. Jan-Urban Sandal, Executive Director and Owner at the Fil. Dr. Jan-U. Sandal Institute (Excellence in Science and Education). 
підприємець - це самомотивовані, кваліфіковані та досвідчені люди, які працюють над тим, щоб зробити щось нове, те, що може внести зміни у напрямі покращення життя всіх у суспільстві. Їх мотивація, в основному, - не прибуток, вони бажають зробити світ кращим, однак соціальні підприємці отримують прибуток, якщо інновація буде успішною. Проаналізовано, що трактування та розуміння економічного розвитку суттєво впливають на філософію, прийняту державою для управління. Так, разом з аналізом взаємозв'язку соціального підприємництва та економічного розвитку, досліджено основні цінності економічних теорій та їх зв'язок із соціальним підприємництвом. Представлено успішні приклади соціального підприємництва Непалу для виокремлення ролі підприємництва у покращенні життя. Обгрунтовано, що соціальний підприємець є стихійним поняттям, однак роль держави на шляху заохочення функціонування соціальних підприємців та збільшення темпів економічного розвитку є важливою. Економічний розвиток повинен відображатися на загальній ситуації в суспільстві, де кожен має можливість розвиватися і всі мають гарне життя.

Ключові слова: капіталізм; економічний розвиток; інновації; соціалізм; соціальне підприємництво.

Introduction. The bitter truth is that countries with high GDPs have alarming situations of poverty. The basic proposition of capitalism is that left alone without any hindrances from the state, the economic system performs satisfactorily. However, its much emphasized general feature is that it is an economic of 'riches' which promotes inequalities in income distribution. On the other hand, socialism, as an opponent concept of capitalism, was believed to benefit the society by centralized planning, full employment of the labor force, and the elimination of the evil of economic inequalities. Nevertheless, socialism is also not free from criticism. Because with the concept of centralized planning, many types of freedom have to be curbed and what little economic success has been achieved is at the cost of democratic values.

Literature review and the problem statement. The focus of problem of the study is whether it is the government who innovates and builds the foundation of development or the individuals in the society, called social entrepreneur, who are the real drivers of the process of economic development.

The method of the study includes a review of theories related to entrepreneurship and profits. Similarly, a few selected cases of entrepreneurship have been collected, reviewed and analyzed with a view to social entrepreneurship and the motives of entrepreneurs.

Full capitalism and full socialism are the expression of the politicians to highlight their agendas to make their people fool, because there are many observations that the most regarded capitalist system of the USA also has some state policies that has direct relation with the concept of socialism and the societies like China and other who still keep their state value of to be full socialist projected towards the communism as their last goal also currently seems to be adopting capitalist model of development.

Very often economic development is regarded as economic growth. Economic development should not always be advocated with indicators of growth and national income. For Amartya Sen, economic growth is only one aspect of the economic development process. Growth is vital but growth alone does not guarantee development [26]. Sen's work has shifted the paradigm from the old framework of income, growth and utility towards increased emphasis on individual entitlements, capabilities, freedom and rights [18]. Economic development significantly should be taken from the social viewpoints because social economy should be the essence of the economic reality.

Research results. To enter into the core objective of this essay, I recall my general understanding of capitalism, socialism and communism. Capitalism is the system based on the ideology of private ownership of assets and all means of production, and operation of production process for the basic motive of profit. Mercantilism is the early form of capitalism. Currently, many economists argue that present stage capitalism is crony capitalism, which creates a nexus between politics and business groups with a motive of accumulation of money without taking any business risks. This is much debated in the developing world.

In contrast, communism is an ideology and the system of social organizations where all property and the resources is owned by the community, each person contributes in the production process as per the capacity and distribution of the output is made according to the ability and need of individual. Socialism, on the other hand is a political and economic theory of social organization controlling the means of the production, distribution and exchange, which is owned and regulated by the community as a whole.

Societies are not simply capitalist or socialist because all societies have some features of both. Even socialist features are to some extent present in the United States, a society that is called more capitalist than others and gradually more so over the times [9]. Marx's study of the genesis of capitalist production process rose up in feudal class giving rise of capitalist enjoying ownership of means of production and labor class owning nothing except their labor power. The accumulation of socially produced wealth emerged as capital and gave ground for the establishment of capitalist relation [12]. There are many countries in the world claiming to be socialist societies but capitalism is still in center of the academic discussion. Many scholars even in American society have said that capitalism is almost in a coma, but at the same time there are other scholars who without mentioning the word capitalism strongly advocate capitalist values.

Classical economists Adam Smith and David Ricardo focused on three factors of production: land, labor and capital. Marxian philosophy considers labor as the key element of production. Marx's model of surplus value shows three circuits of money capital, where the money is at the initial stage if it is put in place as capital resulting in 
a surplus through the production and again used as capital. They are the labors who convert the initial money capital into its original plus surplus value, which is reused in the production again to generate surplus in the subsequent stages. Neo-classical economists elaborated the concept with an alternate theory of value and distribution. They introduced the concept of financial capital, working capital and technology. More recently, entrepreneurship has been taken as the fourth factor and the concept of the entrepreneur, human capital and technology [28] has been added.

By his early training, Karl Marx is a neo-Hegelian. From his German upbringing, he derived the materialistic theory of history, and from his later experience, he acquired the point of view of liberal-utilitarian school, which dominated English thought throughout his life. The standpoint of neo-Hegelian Marxism is forgotten and cannot be regained [28]. If a human being goes beyond the spontaneous production of the nature, he forcefully has to go to industrial production. The large volumes of production are not the creation of nature, they are the creation of industries [15]. Inequality is not an accident but it is the core feature of capitalism. Capitalism needs reform, because without reform, democracy will be threatened [19]. Piketty argues that over the long run, the rate of economic growth is more than the rate of return; as a result, there will be a concentration of wealth and this unequal distribution of wealth causes social and economic instability. He proposes a progressive annual global wealth tax and a progressive income tax to reduce inequality. However, his idea is criticized on the basis that his theory of long term growth exceeding the rate of return is not supported by any empirical study [30]. Irrespective of the criticism over the ideas, one thing is clear: unequal distribution is sure to promote inequality and economic instability. Piketty goes wrong for exactly the same reason Marx and before him Ricardo went astray, although their work for a sweeping theory of inequality and the ensuing debates over inequality are healthy and constructive. Because for any plausible theory of nature and the evolution of inequality, political and economic institutions have to be focused, the endogenous evolution of technology has to be recognized from the institutional and economic and demographic factors, view point to make the existing political and institutional equilibrium can be modeled to manage the shocks and opportunities in an economy [1]. It is of course a proven historical fact that many ideas in history over time change and lose their original form and get developed in a new way, as if they had emerged on their own.

Socialism by no means is an invention of nineteenth century Marxism but is much older. On the other hand, capitalism is a system based on the explicit recognition of private property and non-aggressive contractual exchange between the owners. There must be varying types and degrees of socialism and capitalism where private properties are respected or ignored as per the clear course of treaties [9]. The understanding of the nature, system and characteristic of socialist public finance are important matters in the development of a socialist revolution and social reconstruction. The matters of distribution are established in the foundation of production. Distribution cannot be done without production. Naturally, in socialist public finance, where there is large volume of production of socially usable goods, after considering the basis of distribution, the state can step in the appropriate portion of the production for public distribution [32]. This indicates that focusing only on distribution cannot be possible, because distribution significantly relates to industrial output obtained through the process of production.

In the past people were found to relate the economic development of countries with the geographical location, natural resources, capital resources, labor and many other things. It can be said that the basic equation production function is the same, but different new concepts developed through economic history have found to influence the production function.

Enterprise is the fourth factor of production after land, labor and capital. Enterprises are the results of the entrepreneur's creative enthusiasm. In the economic development process, entrepreneurship is the essential input required. It is the entrepreneur, and only the entrepreneur, who coordinates and brings together all the factors of production for the production process to produce the output.

One of the important concepts developed along with economic history is entrepreneurship. Creation of a new venture, hard work, assumption of risks and reaping of rewards are the main features of entrepreneurship [2]. Entrepreneurs introduce innovations and are catalytic agent and engines for economic development [2].We can find mixed evidence on the role played by entrepreneurship in economic history. Our insight into the role played by entrepreneurship has been limited by the heterogeneities [3]. Historical research on entrepreneurship started much earlier, and it has been aligned with understanding the process of economics, which has been commonly utilized as the Schumpeterian meaning of entrepreneurship [29]. Social entrepreneurship has been seen as the alternative for the public or the community or the responsibility of the government of a country [7]. Studies show entrepreneurship, even if being an individual effort at the initial stage, later can turn out well by joining the public sector.

It has been perceived that entrepreneurs, by exploiting an innovation, and more generally, exploiting an untried technology for producing a new commodity, or producing an old thing in a new way, or by opening up new source of materials or an outlet for products, or by reorganizing an industry and so on, revolutionize and reform the production pattern [25]. The function of the social entrepreneur also includes revolutionizing the development by new invention and replacing an old product or service delivery [25]. These initiations of the 
entrepreneurs, the part of necessity of the life of the society and contribution to economic development once their innovation becomes successful. Entrepreneurship involves the free and independent act of combining the factors of production for the first time, which has not been in the market previously. The motive of this endeavor is to introduce social service to bring improvement in people's lives [22; 21]. With its dynamism in the process, social entrepreneurship, while bringing profit to the entrepreneur, gives society new possibilities in the market and in the society. Introduction of a new good or new method of production, opening of new market, conquest of new source of raw material and a new organization to carry out the industry are the five important areas of innovation $[25 ; 22]$. In a new way that improves people's lives, the process of social innovation combines the factors of production [22]. In this process the entrepreneur acts with high risk for increased results in social value. If unsuccessful, the entrepreneur loses the confidence of society but can be rewarded with entrepreneurial profit if successful [22]. Economic development can be the result of successful social entrepreneurship by which equal rights, a better world, peace, freedom, a more secure society for everyone and technological, economic and social progress can be possible.

Stability is the key indicator of a successful society. Social entrepreneurship, to be successful, must act as generator of socially-oriented economic development needs systematic approach to integrate it with overall economy of the country [14]. In the emergence of business history, entrepreneurship played a formative role. The Schumpeterian definition of entrepreneurship has been typically employed by historical researchers, which primarily focused on varying forms of innovative activity and roles played by business, industry, and the economy. Recent management scholarships primarily focused on new firm formation [29]. Firms are necessary instruments to carry out any venture by any entrepreneur. Recommending for bridging the chasm between political elite and marginalized citizens in the middle-east [7], emphasizes the important role played by social entrepreneurship. Social entrepreneurship is not only a new coat of paint in an old building but it also changes the foundation for better social transformation [7]. Social entrepreneurship not only can act as change agent for a particular society but it can boost the overall economy of a country. For developing countries social entrepreneurship is vital for new innovation in the market and creating new job opportunities, poverty alleviation and enhancing social investment and to unlock economic inclusion and growth [13]. Promoting entrepreneurship puts emphasis on promoting the young population in entrepreneurship. There should be a very coherent political, economic and social system. All of the aspects of the society should be friendly to entrepreneur's young generation. The only need is we must build the widest possible financial and institutional arrangement [8]. This initiation can make the society conducive to the emergence of social entrepreneurs. Entrepreneurship in the early days was taken as phenomenon of interest for economists only. Entrepreneurship shall be seen with differing views for its better understanding, because it is a multifaceted phenomenon which cannot be interpreted from the view point of a single thought or branch of science [6]. Entrepreneurships shall be seen in totality of the economic and social context. Social entrepreneurs are unsalaried people managing the production function. They will be remunerated by entrepreneurial profit only when successful [23]. In a socialist, wage-earner, valuebased society, wage earners are forced to be the borrower, but social entrepreneurship not only promotes democratic and economic development but shifts the role of wage earner from a mere borrower to becoming a lender [21]. This will ensure that the society is better place for all to live.

Different theories of profits have evolved over the time of economic history. The main theories of profit have been The Contemporary Theory of Profit, Profit due to Monopoly of Friction, Profit due to Technology and Innovation and Managerial Efficiency theory. These theories are complementary to each other and not mutually exclusive [4]. However, consensus among economists about the nature of profit and its origin could not be found. As a result of this, various theories pertaining to profit have emerged. Few of such theories are Walker's Theory of Profit, Clark's Dynamic Theory of Profit, Hawley's Risk Theory of Profit, Knight's Theory of Profit and Schumpeter's Theory of Profit. Monopoly Power as source of profit is dealt with separately [5].

Simply put, an entrepreneur is a person who carries a venture to accumulate something more in his capital, which has been termed as profit. Social entrepreneurs are primarily involved in revolutionizing the development of new invention to replace an old product or service delivery in a new way. They are managing the production function and will be remunerated by entrepreneurial profit only when successful.

In this globalization era, complex collective problems, which emerge to affect various dimension of local context, cannot be solved by planning and incentives only. A social entrepreneur is a person who recognizes the economic and social problem, uses the approaches, methods and principles, and establishes a venture. Sectorial demarcation like private, public and community is be blurred. These fundamental features of social entrepreneurs really make them the change makers. Social entrepreneurs target unjust and unsustainable systems and transfer them into entirely new, superior and sustainable forms [20]. Social entrepreneurs can revolutionize the economic and social transformation process.

The traditional water mill still being used in many parts of rural Nepal is an example of Nepal's indigenous technology. Traditionally developed and used for grinding the food grains, mills now have been developed to 
generate electric power as well with required modification. A video from the internet [31] depicts a good example.

Another example is from twin researchers RamLaxman Rimal who now manage a company involved in promoting new and innovative technology in Nepal. They have fifty inventions with patents of five of total innovations. Their innovations include the water pump, wireless community siren system, electronic voting machine, GPS Nepal applications, automatic door access systems, and many more.

The most known contemporary social entrepreneur from Nepal, Dr. Mahabir Pun, is now running an institution named National Innovation Centre (NIC). Dr. Pun, a Ramon Magsaysay Award winner, has been working in Nepal leading the newly established NIC. He is a popular innovator and social entrepreneur of Nepali society. His innovative idea of educating children in rural Nepal with the use of wireless networks has significantly contributed to rural school education [10]. Among the important innovations achieved by him and his institution include the Sabji Kothi (low cost portable vegetable storage), Alternative Protein (alternative animal protein for poultry), Medical Drone (a drone developed by him and his colleague Nepali Engineers for transporting medicine to rural areas of Nepal without access of transport facilities) and Baby Incubator (an incubator to save premature babies in rural Nepal). The vision and mission statement of the institutions mentioned making Nepal prosperous through research, innovation and technology and to provide a platform for innovation [17].
The growth of enterprises in Nepal is slow and the enterprises are sick or closed due to various reasons [2]. Although supporting every entrepreneur from the side of the state may be important from the perspectives of modern economic development, analyzing with a Schumpeterian point of view the social entrepreneur is crucial.

Conclusion. A review of economic history, various empirical analyses, and the work and views of contemporary economists indicate the authoritarianism regime has played a positive role neither in securing high economic growth nor in achieving overall economic development.

Economic growth as indicated by GDP alone is not a sign of economic development. Economic development shall be reflected in the total situation of the society, where everybody has the opportunity to develop and all have a good life.

Innovation is the independent action of social entrepreneurs. Even in a situation where the state itself is not innovation friendly, social entrepreneurs, whose main objective is to find out something for the public benefit, keep going. However, the pace of the real development may be faster if the state's economic policy is integrated with scientific policy encompassing innovation promotion policy. Recognizing the role of the state, we should bear in mind that economic development is not to be seen with a mere emphasis on the emerging or preceding economic status but as a mirror of total situation of the society.

\section{References:}

1. Acemoglu, D. \& Robinson, J. A. (2015). The rise and decline of general laws of capitalism. Journal of Economic Perspectives, 29(1), 3-28. DOI: 10.1257/jep.29.1.3.

2. Agrawal, G. R. (2010). Entrepreneurship Development in Nepal (2067th ed.). Kathmandu: M.K. Publisheres and Distributors.

3. Audretsch, Keilbach \& Lehman (2014). Entrepreneurship and Economic Growth. ReseachGate. DOI: 10.1093/acprof.

4. Bhardwaj, D. (2018). 4 Main Theories of Profit. Retrieved from www.yourarticlelibrary.com/.../4-main-theories-ofprofit/82113.

5. Business Jargons (2018). Types of Profit. Retrieved from https://businessjargons.com/types-of-profit.html

6. Cherukara, J. \& Manalel, J. (2011). Evolution of Entrepreneurship theories through different schools of thought. Evolution.

7. Doumit, G. (2018). Social Entrepreneurship: A Force for Political. Standford Social Innovation Review, 4-7.

8. Drayton, W. (2006). Everyone a Changemaker: Social Entrepreneurship's Ultimate Goal. Innovations: Technology, Governance, Globalization, 1(1), 80-96. DOI: 10.1162/itgg.2006.1.1.80.

9. Hoppe, H.-H. (2010). A Theory of Socialism \& Capitalism. In Ludwig von Mises Institute. Retrieved from mises.org.

10. InternateHallofFame. (2020). Mahabir Pun's Wireless network of school education.pdf. Retrieved from https://nicnepal.org/projects/alternative-protein.html website: https://www.internethalloffame.org/inductees/mahabir-pu.

11. Kapoor, A. \& Debroy, B. (2019). GDP Is Not a Measure of Human Well-Being. Harvard Business Review. Retrieved from https://hbr.org/2019/10/gdp-is-not-a-measure-of-human-well-being.

12. Katz, C. J. (1993). Karl Marx on the transition from feudalism to capitalism. Theory and Society, 22(3), 363-389. DOI: 10.1007/BF00993533

13. Kazmi, S. S. A., Hashim, M., Kee, D. M. H. \& Khan, F. U. (2016). Social Entrepreneurship and its Impact on Economy: In Perspective of Pakistan. International Journal of Academic Research in Accounting, Finance and Management Sciences, 6(4), 161-166. DOI: 10.6007/IJARAFMS/v6-i4/2334

14. Kostetska, I. \& Berezyak, I. (2014). Management Theory and Studies for Rural Business and Infrastructure Development Social Entrepreneurship As An Innovative Solution Mechanism Of Social Problems Of Society. Management Theory and Studies for Rural Business and Infrastructure, 36(3), 1822-6760.

15. Marx, K. (1847). The Poverty of Philosophy. La Emancipacion. Retrieved from https://www.marxists.org/archive/ marx/works/download/pdf/Poverty-Philosophy.pdf 
Електронне наукове фахове видання з економічних наук “Modern Economics», №19 (2020), 143-148 https://modecon.mnau.edu.ua | ISSN 2521-6392

16. MyRepulica (2017, March 8). Ram-Laxman Young innovator of Nepal.pdf. My Republica. Retrieved from https://myrepublica.nagariknetwork.com/news/nepal-s-young-innovators-ram-alxman.

17. NIC (2020). About NIC. Retrieved from https://nicnepal.org/about/

18. ODI (2001). Economic Theory, Freedom and Human Rights: The Work of Amartya Sen. Briefing Papers, (20), 1-2.

19. Piketty, T. (2014). Capital in the Twenty-First Century (Translated). Cambridge, Massachusetts London, England 2014: The Belknap Press of Harvard University Press.

20. Roseburg, R. L. M. S. R. (2015). How social entrepreneur make change happen.pdf. In Getting Beyond Better. Retrieved from https://hbr.org/2015/10/how-social-entrepreneurs-make-change-happen.

21. Sandal, J.-U. (2014). The Imporatance of Innovation for Democratic and Economic Development in Europe. Economika. Retrieved from https://janusandal.no/en/about/publications.

22. Sandal, J.-U. (2016). Social Entrepreneurship in Theory and Practice: Promoting Entrepreneurship in Different Social Groups. ALYTUS COLLEGE, Academic Pappers, Nr. 1(2).

23. Sandal, J.-U. (2018). Models and innovative approaches to Social entrepreneurship Social. Fil.Dr.Jan-U. Sandal Institute.

24. Schumpeter, J. A. (1942). The-Theory-Of-Economic-Development.pdf. Harvard University Press, 1-266.

25. Schumpeter, J. A. (1997). Capitalism, Socialism and Democracy. In Foreign Affairs (Vol. 76). DOI: 10.2307/20048211.

26. Sen, A. (2020). Economic Development. Retrieved from https://www.economicsonline.co.uk/Global_economics/ Economic_development.html.

27. Squazzoni, F. (2009). Social entrepreneurship and economic development in Silicon Valley: A case study on the Joint Venture: Silicon Valley Network. Nonprofit and Voluntary Sector Quarterly, 38(5), 869-883. DOI: 10.1177/0899764008326198.

28. Veblen, T. (1907). The Socialist Economics of Karl Marx and His Followers. The Quarterly Journal of Economics, 21(2), 299. DOI: $10.2307 / 1883435$.

29. Wadhwani, R. D. \& Jones, G. (2006). Entrepreneurship and Business History : Renewing the Research Agenda. Harvard Business School Gjones, 51.

30. Wikipedia (2020). Capital in the Twenty-First Century.

31. Youtube (n.d.). Retrieved from https://www.youtube.com/watch?v=vdq7P1z1Yus.

32. Yung, S. (1968). The substance, characteristics, and system of socialist public finance. Chinese Economic Studies, 2(2), 3-27. DOI: $10.2753 /$ CES1097-147502023.

Ця робота ліцензована Creative Commons Attribution 4.0 International License 